\title{
Етноніми в українських діалектах: від номінації до наївної аксіології
}

\author{
ІННА ГОРОФ'ЯНЮК \\ Кафедра української мови, Вінницький державний педагогічний університет імені \\ Михайла Коцюбинського, вул. Острозького, 32, UA-21001 Вінниця \\ Department of Ukrainian Language, Vinnytsia M. Kotsiubynskyi State Pedagogical University \\ E-mail: gorofyanyuk@gmail.com
}

(Received: 4 May 2018; accepted: 23 July 2018)

\begin{abstract}
The aim of the present paper is to characterize types of information which can be received from studying the Ukrainian dialect vocabulary derivated from ethnic names. The possibility to reconstruct the notions of Ukrainians about ethnic groups through the analysis of motivating means of secondary coinage is outlined. In the paper, the author attempts to recreate the axiological portraits of Gypsies, Jews, and Poles on the basis of facts of naive knowledge about the subject incarnated in the internal form of dialectal lexical units.
\end{abstract}

Keywords: ethnic names, Ukrainian dialects, motivation, secondary coinage, axiological portrait

У живому говірковому середовищі слово перебуває в чистій стихії буття, не обмеженій приписами чи нормами, а тому має простір для вияву його різних вимірів. Аналіз етнонімів у контексті наївної картини світу має високий евристичний потенціал, адже «вживання етноніма викликає у свідомості мовців згорнуті в єдиний образ спогади про попередні контексти його вживання, оцінки відповідних референтів та ставлення до них» (КАшкин 2000: 64), етнонім породжує конкретну модель дій і оцінки або, точніше, стереотип. Саме тому аналіз етнонімів, які стали базою для творення діалектних назв понять різних ідеографічних сфер, дозволяє, з одного боку, простежити буття мови в соціумі, а з другого боку, долучитися до пізнання етнокультурних стереотипів народу, закарбованих у його мові.

Переконливий матеріал для вивчення етнонімів, маркованих етнокультурною конотацією, дає сучасна діалектна лексикографія. Можливість простежити культурний фон низки етнонімів у говірковому середовищі значно вища, що спричинено відсутністю в ньому обмежень стосовно «політичної коректності» та більшою розкутістю самої мовної техніки (БЕРЕзОвич-Гулик 2002: 48). Крім того, на різних територіях відбувалися контакти «місцевого значення» 3 представниками сусідніх етносів, що також відображається в діалектних відетнонімних дериватах, що не $є$ релевантним для літературного ідіому. Це окреслює мету нашої розвідки - дослідити та систематизувати факти втілення знань про представників інших національностей в українській діалектній лексиці. Емпіричну базу формують 272 номінативні одиниці - 
відетнонімні деривати, вилучені методом суцільної вибірки з 27 українських діалектних лексикографічних праць.

Діалектна лексика, співвідносна з назвами представників етнічних груп, етимологічно на перший погляд здається прозорою, та докладніший iї аналіз засвідчив неоднорідність відетнонімних похідних з точки зору їхніх мотиваційних зв'язків з відповідними назвами етнічної приналежності та їхнього культурного тла. До прикладу, ботанічні апелятиви, похідні від одного етноніма, як найменування різних рослин мають різні мотиви номінації. Так, назви лепехи звичайної, Acorus calamus L. - татара, татарка, татариня, татариник, татарник, татар-зілля, татарове зілля, татарче зілля, татарське зілля, татарськиц корінь (КоБІв 2004: 38), татарак (Аркушин 2016: $547)$ - зумовлені тим, що цю рослину занесли на українську землю татаромонголи (САБАдош 1996: 113). Натомість флороназва татарник відома також у центральноподільських говірках на позначення черсака лісового, Dipsacus sylvestris Hud., імовірно, постала на грунті асоціацій високої колючої рослини зі страшним ворогом - татарами. На користь цього припущення свідчить назва татарник - широко відома на позначення колючих рослин в українських говорах: будяк пониклий, Carduus nutans у західно- і східнополіських говірках (КобІв 2004: 102), осот польовий, Cirsium arvense L. у слобожанських і степових говірках (КоБІв 2004: 129), головатень круглоголовий, Echinops sphaerocephalus L. у степовому (КоБІв 2004: 167), оман жорстковолосистий, Inula hirta L. у гуцульському (КоьІв 2004: 230) говорах (докл. див. ГороФ'янюк 2010). У такий спосіб відетнонімна назва рослини закарбовує оцінку мовця самого етносу.

Спостережено, що всі відетнонімні деривати - семантичні чи морфологічні - виконують денотативну функцію, а ті, що наділені ще й відповідною конотацією, є джерелом наївної аксіології.

Як засіб лексичної номінації реалії (переважно формальної) етноніми використовуються як опосередкована вказівка на поширення, колористичну характеристику реалії. Відетнонімні деривати, мотивовані способом поширення чи джерелом розповсюдження реалії, найактивніше представлені в ботанічній лексиці. Ця група містить родові назви рослин, як-от: ка'надка 'галінсога дріброцвітна, Galinsoga parviflora Cav.': Бо иее 'кажуm / з Ка'нади за'-

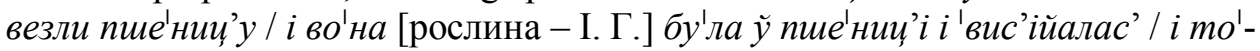
д’i кру'гом во'на // (с. Василівка Іллінецького р-ну Вінницької обл., 2009 р., зап. І. В. Гороф'янюк). 3 етнічною назвою грек пов'язана номенклатурна назва гречки посівної, Fagopyrum tetaricum L. - гречка, що відбиває шлях поширення рослини у східних слов'ян - через греків (ШАмотА 1985: 24), в українських говірках відома й інша назва цієї рослини - татарка (Турчин 2011: 311). Імовірно, у номінації кацапські квітки 'айстра садова, Callistephus chinenis L.' (ГоРОФ'янюк 2012: 187) проступає та сама мотивація, що й у попередніх назвах, у яких відбито шлях поширення рослини. Номінативний ряд 'фенхель звичайний, Foeniculum vulgare Miller' містить найменування волоський кріп, копрій волоськиц̆, укроп волоський (КоБІв 2004: 189), атрибутивний 
компонент яких, імовірно, також вказує на джерело розповсюдження рослини. І. В. Сабадош та В. Будзішевська висувають припущення, що флорономени волошка, волошки, волошка польова 'волошка синя, Centaurea суаnus L.' постали внаслідок переосмислення лексеми волошка 'жінка романської народності', отож виділяють мотиваційне значення 'завезений певним народом’ (САБАдОш 1996: 136, BuDZISZEWSKA 1972: 117).

Проте найбільшу кількість ботанічних номенів, мотивованих способом поширення рослини, фіксуємо серед видових назв сільськогосподарських $\mathrm{i}$ плодових рослин. В українському діалектному континуумі засвідчено широкий ряд назв сортів картоплі, Solanum tuberosum L., пов'язаних з етнонімами: голандка, канадка, канатка, кубинка, молдаванка, ромінка, румінка, руминка, украӥнка, слов'янка, слав'янка, американка, маріканка, марикани (ГОРОФ'янюк 2012: 46-48), мадярка (СУГО 2011: 425), чехи, мадярка, циган$\kappa a$ (КоБІв 2004: 386-387). Домінування варіантів флороназви американка підтверджує факт завезення картоплі з Північної Америки в кінці XV ст.

Відомі назви сортів кукурудзи звичайної, Zea mays L. американка, басарабка, молдаванка, молдованочка, молдовочка (ГоРОФ'янюк 2012: 45). Превалювання назв, похідних від молдаванка - свідчення шляху проникнення культури, зокрема на Поділля, адже в інших українських говорах зафіксованих назв сортів кукурудзи, похідних від етнонімів, наразі не маємо.

Етнонім татарка вживають на позначення сорту дині, Cucumis melo L.' (КоБІв 2004: 147), сорту квасолі (КоБІв 2004: 308), сорту гречки (КоБІв 2004: 184), пшениці твердої, Triticum durum Desf. (КоБІв 2004: 416), ярої пшениці (СБГ 2005: 540), картоплі (ПІПАш-ГАЛАС 2005: 189). За свідченням Й. О. Дзендзелівського, назва татарка вживалась на означення гречки в закарпатському, говорі й пов'язувалась 3 татарською навалою (ДзЕндзЕлівський 1960: 115-116). I. В. Сабадош припускає, що назви гречка і татарка 'гречка, Fagopyrum tetaricum L.' вказують на відмінні шляхи проникнення до нас різних видів сільськогосподарської культури (САБАдош 1996: 97).

Вид часнику городнього, Allium sativum L., номінований москаль, москальник, за Словником за ред. Б. Грінченка (СУМ 1908: 447), імовірно, одержав такі назви у зв'язку з походженням його з Росії (ЕСУМ 3: 519).

3 огляду на локалізацію відетнонімних похідних у говірках південнозахідного наріччя української мови, припускаємо, що виникнення назв одягу та взуття полька 'жіночий теплий одяг' (СДЛВ 1965), молдова́нка 'смушева чоловіча шапка' (СБГ 2005: 295), румінки 'теплі жіночі черевики' (СУГО 2011: 175, БЕРЕЗОВСЬКА 2010: 252), румункі 'Вид жіночого теплого взуття (заст.)' (СБГ 2005: 470) також пов'язане з джерелом розповсюдження реалії. Цю ж мотивацію простежуємо в назві руму́нка 'вівця румунської породи' (ОНИшКЕВич 2: 197).

Не викликає сумніву мотиваційна ознака метеорологічних народних номенів молдава́н 'західний вітер, вітер з Молдови' (СУГО 2011: 129, МоскАлЕнко 1974: 51), молдавка 'вітер, що дме $з$ північно-західної частини Бессарабї' (СУГО 2011: 129, МоскАЛЕНКО 1974: 51). 
Другу групу становлять лексеми, пов'язані з етнонімами, утворені на підставі зовнішніх ознаках реалії. Поширеною є мотиваційна ознака «забарвлення». Найактивніша твірна основа - циган, з огляду на темний колір шкіри представників цього етносу: цица́нка 'вівця темної масті' (ПІПАш-ГАЛАС 2005: 214), ‘чорна вівця' (СБГ 2005: 623), цииган 'чорний баран' (СБГ 2005: 623), цигани 'підгорілі коржі' (Аркушин 2016: 595). Найактивніше функціонує ця мотиваційна ознака у флорономінації: цига́нка 'сорт картоплі з темносиньою, аж ніби чорною шкіркою’ (Аркушин 2016: 595), 'сорт червоних яблук’ (Шило 2008: 269), 'горошок чорний, Lathyrus niger L.' (КоБІв 2004: 244), 'чорнобривці розлогі, Tagetes patula L.' (Кобів 2004: 399), цича́ни 'чорні гриби’ (Шило 2008: 269), ции́ган 'їстівний гриб, який при розрізанні швидко синіє' (СБГ 2005: 623). Темний колір шкірки окремого сорту картоплі, Solanum tuberosum L. зумовив переосмислення етнонімів негри, негритянка, нєгрітянка (ГороФ'янюк 2012: 47). У номінаціях негр 'сорт помідорів, Lycopersicom esculentum L.' (ГороФ’янюк 2012: 47), арапка 'сорт яблук, Malus domestica Borkh.' (КовІв 2004: 267) проступає та ж мотивація, що і в попередніх назвах, у яких метафорично відбито темний колір плоду.

На позначення сорту квасолі звичайної, Phaseolus vulgaris L., зерно якої має вишневу позначку своєрідної форми, у подільських говірках зафіксовано назви мос'калики, з мос'каликами (ГороФ’янюк 2012: 48). Номени постали, припускаємо, унаслідок асоціативного зв'язку забарвлення частини рослини 3 яскравим одягом солдат-росіян. Припущення будуємо на грунті запропонованої етимології назви комахи мос'калик 'сонечко п'ятикрапкове, Coccanella quintempunctata L.', відомої в українських говірках - москалик 'червоний жучок з чорними плямками' (СДЛВ 1965), моска́лик 'назва комахи, що з’являється ранньою весною’ (СУГО 2011: 130) - в «Етимологічному словнику української мови» (ЕСУМ 3: 519).

Мотиваційна ознака «великий розмір» лежить в основі діалектних найменувань, пов'язаних з етнонімами цизан. Підсніжник звичайний, Galanthus nivalis L. у закарпатському говорі номінують козиньки (КоБІв 2004: 194), водночас на позначення білоцвіту весняного, Leucojum vernum L. - рослини, зовні подібної до підсніжника звичайного, лише з більшими квітами - зафіксовано полікомпонентну назву ц̧и'ганс'кі козин'ки (КоБІв 2004: 251). Означення цииганський має сему 'великий розмір' в різних ідеографічних сферах, пор.: циганчук 'великий саморобний ніж 3 дерев'яною ручкою' (Аркушин 2016: 595), цицанка 'велика голка' (Лисенко 1974: 228), цүиа́нська гла ‘велика голка' (Шило 2008: 269), цчиганська голка 'велика голка, якою шиють мішки' (СДЛВ 1965), цзыганские ложки 'большие деревянные ложки' (СРГО 20002001: 269), вуса, як у цүи́гана 'великі вуса' (ГС 2013: 630). Прикметно, що ця сема відома і в неслов'янських мовах: так, Оксфордський словник англійської мови містить сталі вислови gipsy-bonnet 'циганський капор', gipsy ring 'циганський перстень', що мають сему ‘великого розміру' (OED 1989: 524). Це дозволяє припустити, що семантичний зв’язок 'циган' - 'великий розмір' $€$ міжмовною лексико-сематичною універсалією. 
Ословлюючи світ, людина не лише називає, а й характеризує, оцінює. Назви представників інших етносів зазнають стереотипізації: формуються відповідні уявлення про представників інших етносів, які необхідні для творення нашого ставлення до чужого народу, моделі поведінки 3 ним. «Завдання виявлення стереотипів національних характерів може буде зведене до завдання виявлення конотацій в етнонімах..., точніше таких їхніх необов'язкових семантичних ознак, які несуть інформацію про риси характеру» (КоБозевА 2000: 185). В українських діалектах корпус конотованих етнонімів або відетнонімних дериватів формують лексеми циган, жид, поляк та їхні похідні. Цей ряд для українців не випадковий, а зумовлений тим, що в національній концептосфері дається оцінка лише тим одиницям, які більшою або меншою мірою значимі для цієї культури, це або територіально близькі (поляки), або історично пов'язані народи (євреї, цигани, турки, німці, росіяни), адже «вживання відповідних етнонімів викликає у свідомості мовця згорнуті в єдиний образ спогади про попередні контексти його вживання, оцінки відповідних етнічних груп, емоційне ставлення до них» (докл. див. КАшкин 2004: 54).

У народній культурі ставлення до представників інших етносів визначається поняттям етноцентризму, коли «свої» традиції, «своя» релігія, «свої» звичаї і «своя» мова протиставляються «чужому» (БЕЛовА 2006: 2). Категорія «свій - чужий» виявилася універсальним класифікатором етнокультурних стереотипів, оскільки етнонім має здатність умовно позначати певний об'єкт як чужий, дикий, шкідливий. Найчастіше фіксуємо це явище у флорономінації, зокрема в називанні шкідливих і дикорослих трав, що можна інтерпретувати як метафоричне вираження ідеї неокультуреності і навіть контркультури. Це назви рослин, похідні від назв 10 етносів:

1) румун-: ромун 'ромашка лікарська, Chamomilla recutita', 'польова ромашка непахуча, Matricaria perforata' (КоБів 2004: 122, 270), ромен 'роман польовий, Anthemis arvensis' (Ковгв 2004: 58), 'роман собачий, Anthemis cotula' (Ковгв 2004: 59), 'ромашка лікарська, Chamomilla recutita' (КоБів 2004: 122), ‘королиця звичайна, Leucanthrmum vulgare' (КоБІв 2004: 251), 'польова ромашка непахуча, Matricaria perforata' (Ковгв 2004: 270), ромин, румен 'роман собачий, Anthemis cotuia' (КоБІв 2004: 59), 'ромашка лікарська, Chamomilla recutita' (КоБів 2004: 122), румин 'деревій звичайний, Achillea millefolium' (Ковгв 2004: 34), 'роман собачий, Anthemis cotula' (Ковгв 2004: 59), 'ромашка лікарська, Chamomilla recutita' (Ковгв 2004: 122), румін 'роман собачий, Anthemis cotuia' (Ковгв 2004: 59), 'ромашка лікарська, Chamomilla recutita' (Ковгв 2004: 122), румун 'роман собачий, Anthemis cotuia', 'ромашка запашна, Chamomilla suaveolens' (Коьгв 2004: 59, 122), руму́н 'ромашка безпелюсткова' (АРкушин 2016: 486) руминка, руменка, руменеиь, румунещь, руминок 'ромашка лікарська, Chamomilla recutita' (КоБІв 2004: 122), руминець 'роман польовий, Anthemis arvensis' (КоБІв 2004: 58), руминчик 'роман польовий, Anthemis arvensis' (КоБгв 2004: 58), 'ромашка лікарська, Chamomilla recutita', румунчик 'роман польовий, Anthemis arvensis' (КоБів 2004: 122, 58), 
'ромашка лікарська, Chamomilla recutita' (Ковів 2004: 122), руму́нки 'нагідки лікарські' (СБГ 2005: 470), ромун-зілле 'польова ромашка непахуча, Matricaria perforata' (КовІв 2004: 270);

2) жсид-: жидик 'кульбаба звичайна, Taraxacum officinale' (Коьгв 2004: 401), ‘пухівка вузьколиста, Eriophorum angustifolium' (Ковів 2004: 175), жидівська шапка 'кульбаба звичайна, Taraxacum officinale' (КоБів 2004: 401), жиди, жидики 'череда тридільна, Bidens tripartite L.' (Коьгв 2004: 83), жидівник 'тамариск галузистий, Tamarix ramosissima' (КовІв 2004: 399), жидки 'буквиця лікарська, Betonica officinalis L.' (Кобів 2004: 82), жидник 'осот польовий, Cirsium arvense L.' (Ковгв 2004: 128), ‘будяк звичайний, Carduus acanthoides L.' (КовІв 2004: 101), жиди́вскі во́ши 'череда трироздільна' (Аркушин 2016: 154), жидú 'череда трироздільна' (АстАФ’єВА-Воронич 2014: 499), жиди, жи́дикі 'череда' (ГГ 1997: 70), жидик(и) 'череда' (СБГ 2005: 114), жидівські ву́ші 'реп'яхи' (Шило 2008: 116), жидо́к 'чорнобривець, Tagetes' (Аркушин 2016: 154), жиди́вська лепе́ха 'рослина, що росте в заболочених місцях і цвіте жовтим або синім цвітом; півники болотні, Iris psewdacorus L.; півники болотні, Iris siberica' (АРкушин 2016: 154), жидівка 'галінсога дрібноцвітна, Galinsoga parviflora' (КоБгв 2004: 195), жиди́вка, жидо́вка 'лисичка (гриб), Cantharellus cibatius' (АРкушин 2016: 154);

3) татарин: татарки 'пестач випрямлений, Potentilla erecta L.', mamapник 'волошка синя, Centaurea cyanus L.' (Кобів 2004: 328), 'родовик лікарський, Sanguisorba officinalis L.' (КоБів 2004: 364), 'козельці лучні, Tragopogon pratensis L.' (Кобів 2004: 409), татари́нь 'лопух' (Шило 2008: 250), maтáрина 'татарник, Onopordon' (Лисенко 1974: 211), тата́рни́к 'родовик лікарський’ (Лисенко 1974: 181), татарник 'родовик’ (ПпПАШ-ГАЛАС 2005: 189), татарське око 'дивина чорна, Verbascum nigrum L.' (Ковгв 2004: 425);

4) москаль: москаль, москалик 'кульбаба звичайна, Taraxacum officinale' (Коьгв 2004: 401), москалики 'фіалка собача, Viola canina L.' (Ковтв 2004: 434), москаль 'миколайчики сині, Eryngium planum L.' (КоБів 2004: 177), москаль 'галінсога дрібноцвітна, Galinsoga parviflora' (ГороФ'янюк 2012: 165). Остання флороназва постала внаслідок лексичного субституювання. Адже на позначення рослини миколайчики сині, Eryngium planum L. в українському діалектному континуумі зафіксовано лексеми, похідні від основи микол-: миколаєвки, миколаївиі, миколайки, миколайське, миколайці, миколайчики, миколки, николаєиь (КоБів 2004: 177). Припускаємо, асоціативний ряд Микола-російський цар - очільник москалів-солдатів (саме за Миколи I війська москалів перебували в Україні) спричинив семантичну атракцію із лексемою москаль, відомою у волинському говорі на позначення миколайчиків синіх, Eryngium planum L. (Коьгв 2004: 177);

5) циган: цицан 'волошка синя, Centaurea cyanus L.' (Ковгв 2004: 110), циигани 'куряча сліпота звичайна, Nonea pulla L.' (Ковів 2004: 287), цигануши, циганські вуши 'череда тридільна, Bidens tripartite L.' (КоБгв 2004: 83), циганки 'нагідки лікарські, Calendula officinalis L.' (КоБІв 2004: 92), 'ломиніс цілолистий, Clematis integrifolia' (КоБІв 2004: 131); 
6) мадяр: мадярка, мадяр, мадяри 'галінсога дрібноцвітна, Galinsoga parviflora' (КоБІв 2004: 195);

7) австрієць: австрейки 'королиця звичайна, Leucanthrmum vulgare' (Коьгв 2004: 251), австри́йське 'лобода' (Аркушин 2016: 1);

8) німець: німка 'жимолость татарська, Lonicera tatarica L.' (КоБгв 2004: 259);

9) циган: ииганська вош 'реп'ях' (Шило 2008: 269);

10) американець: американещь 'галінсога дрібноцвітна, Galinsoga parviflora' (Ковтв 2004: 195).

Аксіологічні ознаки «шкідливий», «дикий», «неприємний», які маніфестують у народній свідомості образ представника чужих народів, втілені в зоологічних назвах жидо́чок 'тарган' (СУГО 2011: 76, МоскАлЕНКо 1974: 33), жид 'жук-рогач' (Шило 2008: 116), жидик 'чорний польовий жук' (СУГО 2011: 76), ‘комаха, що завдає шкоди соняшнику' (СБГ 2005: 114), жид 'сонечко семикрапчасте, Coccinelidae’ (АРкушин 2016: 154) (ці комахи у великій кількості можуть завдавати шкоди посівам), австріяк 'світлого кольору бичок з несмачним м'ясом, що водиться на дні Дністровського лиману' (СУГО 2011: 11). Той факт, що наведений лексичний ряд сформовано на базі різних етнонімів спростовує можливе хибне уявлення про негативну оцінку євреїв в очах українців, натомість маємо узагальнено-аксіологічне сприйняття «чужого» в мовній картині світу українців.

Образ татарина проявляє активність у номінації хвороб, актуалізуючи мотиваційну ознаку «шкідливе», «те, з чим потрібно боротися»: тата́рка 'пухлина на тілі', 'туберкульоз суглобів' (СБГ 2005: 540). Загалом така модель вторинної номінації «етнонім» $\rightarrow$ «назва фізіологічного стану, з яким „борються“", який може захопити людину зненацька і супроводжуватися відчуттям пригнічування» активно функціонує в слов'янських мовах (докл. див. БЕРЕЗОВИч 2007: 441-443).

Ще одна складова образу «чужого» - «несправжність, фальшивість». Це мотиваційне значення втілюється в лексиці різних тематичних груп: жиди́вський 'несправжній, лише подібний до чогось' (АРкушин 2016: 154), жидівська курка 'куріпка, птах роду курячих, що живе біля води' (Аркушин 2016: 154), жидівська зазу́ля 'одуд, Uрира ерорs' (АстАФ'єВА-Воронич 2014: 499), жидівська зозуля 'одуд’ (Шило 2008: 116, Никончук 1968: 450), московська зозуля 'одуд' (Никончук 1968: 450), ии'ганс'кі козин'ки 'білоцвіт весняний, Leucojum vernum L.' (КоБгв 2004: 251), жидівські вишні, жидівські груші, жидівські ягоди, яйця жидівські 'міхунка звичайна, Physalis alkekengi L.' (Коьгв 2004: 311), жид ‘блазень' (Негрич 2008: 69).

Усталена занижена, найчастіше негативна оцінка представників інших етносів реалізується в метафоричній мотиваційній моделі «чужий» $\rightarrow$ «дрібний», у якій фігурують похідні від різних етнонімів: жидівські кучки 'маленькі хмарки восени' (ДоБРольожА 2010: 97), жидо́к, жидючо́к 'невеликий складаний ніж’ (Аркушин 2016: 154), німчик 'невеликий складений ніж’ (АРкушин 2016: 348), цицано́к, цииа́нчик 'невеликий саморобний ніж’ (АРкушин 
2016: 595), цигано́к ‘складний ножик' (Лисенко 1974: 228), цига́нчик 'невеликий складний ніж’ (АРкушин 2016: 595), моска́лики 'івасі, сорт дрібного оселедця' (Пиртей 2004: 178), жидівські вушка 'сорт квасолі 3 дрібним зерном' (ГороФ'янюк 2012: 48). Відомі також флорономени жидивські помідори, жидивські баклажани на позначення дрібних помідорів (ПогстоговА 2005: 82).

«Аномальне», «незвичне», «чудернацьке»- мотиваційна ознака відетнонімних найменувань метеорологічних явищ: циганський дощ 'дощ, що йде, коли світить сонце' (Лисенко 1974: 228), польські морози 'зимові дні $з$ дуже низькою температурою' (МАтї̈ 2013: 369), натомість відоме польське $m r o ́ z$ moskiewski 'про сильний мороз' (NKP 1970: 525). Так негативно оцінюване явище природи корелює з еталонним для пейоративної номінації образами «чужих». «Чужий» - це не лише той, що належить до іншого етносу, а й іншої віри. Конфесійно «чужий» для українців єврей та циган, образи яких регулярно фігурують як взаємозамінні. Їм опозиціонує ру́ский (АРкушин 2016: 487), кача́nськ'iŭ 'православний' (АРкушин 2016: 213). Представник «чужої» віри в традиційній народній уяві асоціюється 3 представником іншого, потойбічного світу. Це пояснює функціонування в західноукраїнських говірках відетнонімних похідних на позначення ритуального танцю-гри при покійникові - иигани куйут (ОнишкЕВич 2: 352), жид (ГГ 1997: 70), жид і жидівка (ГС 2013: 262): два юнаки переодягаються на жид та жидівку; жид на плечах тримає торбу (переважно із попелом усередині), наповнену лахміттям. Жидівка втікає та ховається за гравия; жид біжить за нею й б'є того, за кого сховалася жидівка (ГС 2013: 262). Зауважимо, що žid як гра при покійникові відома також словакам та чехам (ЛевкиевскАя 1999: 381).

«Чужий» володіє також іншою, незрозумілою мовою. Відомо, що лексема німець активно вживалась на позначення будь-якого іноземця із Західної Свропи, який не володіє слов'янськими мовами (ЕСУМ 4: 99), а тому мотиваційне значення дериватів від німець- втілено в низці слів різних тематичних груп, об'єднаних спільною семантичною ознакою 'неговіркий': німеи, 'собака, який мовчки гонить звіра', 'глухоніма людина' (АРкушин 2016: 348), німка 'неговірка дівчина, тому що скромна' (Аркушин 2016: 348). У говірках спостерігаємо і зворотній напрям номінаційної моделі: німців назвуть німо́тою (АРкушин 2016: 348).

Реалізація регулярної моделі семантичної трансформації «говорити іноземною мовою» $\rightarrow$ 'говорити незрозуміло' (і далі ‘говорити нісенітниці') спричинила втягнення етноніма німкеня в номінативне поле флорооб'єкта блекоти чорної, Hyoscyamus niger L., де він функціонує паралельно з назвами німиця, немиия, настя німа (Ковгв 2004: 226), оскільки, наївшись ягід блекоти чорної, Hyoscyamus niger L., людина втрачає здатність говорити (САБАдош 1996: 129): Ко' лис' 'ж'інка 'вирвала йі'йі $і$ напо'йіла ди'тину / $i$ ди'тина уун' $i$ 'м'іла / i так і с'тали нази'вати йі'йі н'і'мищейу // (Гороф'янюк 2012: 161). Культурно-історичний контекст зумовив постання фразеологізмів із стрижневим компонентом німиі: німці в хаті 'сварка' та німці мариирують 'безлад, розгардіяш’ (ДоврольожА 2010: 116). 
Узагальнене уявлення про представників чужих етносів як «неокультурене», «примітивне» втілилось у вторинній номінації турок 'дурень, розумно обмежена людина (зневажл.)' (Аркушин 2016: 568) та фразеологізмах зі стрижневим словом-етнонімом: турок шалений 'ужив. для вираження незадоволення чиєюсь поведінкою, діями, вчинками' (ФСЛГ 2013: 235), молдаван він $і$ в Африці молдаван 'дурна людина', 'щось недоречне' (ДоБРольожА 2010: 110), китайська грамота 'нісенітниця' (ДоБРольожА 2010: 49).

Таким чином, у сучасній діалектній лексиці збережено архаїчні уявлення українців про «чужих» - представників інших народів, - образ яких формується з таких аксіологічних ознак, як: «дикий», «неприємний», «шкідливий», «дрібний», «аномальний», «потойбічний», «примітивний», «несправжній», «нездатний нормально говорити».

На грунті цих ознак сформувався і функціонує загальний стереотип етнічно та конфесійно «чужого». О. Л. Березович слушно зауважує, що в реальних біографіях слова, у живій мовній стихії зіштовхується велика кількість імпульсів, які йдуть як від універсальних уявлень про властивостях «чужих», так і від «сутнісних» характеристик представників інших народів (БЕРЕзович 2014: 205).

У цій статті зробимо спробу відтворити аксіологічний портрет цигана, єврея та поляка на грунті фактів втілення наївних знань про суб'єкт у внутрішній формі діалектних лексичних одиниць.

Етнонім циган у лексичній системі українських діалектів має найбільшу кількість семантичних та морфологічних похідних, що вже засвідчує особливе місце відповідного етносу в мовній картині українців. Виявлено такі складові образу цигана:

а) мотив музики, танцю, руху: изита́не-гуда́щ̧ы 'весільні музики' (Пиртей 2004: 333), ииганяска 'чоловічий танець' (СБГ 2005: 623), циганка 'деталь коврітка' (Аркушин 2016: 595), циганочка 'деталь самопрядки, що з'єднує підганялку з віською’ (СУГО 2011: 206), цииган 'дзига' (Лисенко 1974: 228), як иитанска іскра 'дуже енергійний, жвавий' (ФСЛГ 2013: 111);

б) мотив неохайності: як у цитана уш 'багато чого-небудь' (ФСЛГ 2013: 249), як шатрова иитанка 'ужив. для підсилення слова «неохайна»; дуже неохайна' (ФСЛГ 2013: 249);

в) мовив волі, легковажності: иитанери́я 1. 'вільний спосіб життя', 2. ‘група людей, що веде вільне життя' (Пиртей 2004: 333); як иитанске вірую 'непотрібна, зайва розмова' (ФСЛГ 2013: 48);

г) мотив безгосподарності: одкладати як иитан сьвято 'постійно відкладати яку-небудь роботу на потім’ (ФСЛГ 2013: 249); гріти ся як иуианове діти до місяия 'зовсім ні' (ФСЛГ 2013: 77); иитананьской вальок 'дуже повільна, вайлувата людина' (ФСЛГ 2013: 32);

г) мотив нетерплячості: захие ти ся як ичианяті молока, захие ти ся як иитанскому дзецку ягод на сьвятуй вечері 'нестерпно хотіти чого-небудь' (ФСЛГ 2013: 97), забагнути си як у Святом вечеру цитанові ягоды 'нестерпно хотіти чогось' (ФСЛГ 2013: 89); 
д) мотив випрошування: цица́ни 'ті, хто постійно щось випрошує або позичає в сусідів’ (Аркушин 2016: 595), циганка 'прохальниця’ (Аркушин 2016: 595), циига́нити 'випрошувати, виманювати щось у когось' (ДзЕНДЗЕЛІвсьКИй 1958: 45), цииа́нитися 'торгуватися' (СБГ 2005: 623);

е) мотив обману: цчиган 'хитрун' (СДЛВ 1965), ичита́нський 'брехливий, який не викликає довіри' (ПиРтЕй 2004: 333), циитанск’iŭ ‘брехливий’ (СПЛЛГ 2015: 200), циитанити, вицитанити 1. 'брехати, обдурювати', 2. 'виманювати', цитаньство ‘брехня, неправда, обман' (Турчин 2011: 333), цичганота 'обман' (Онишкевич 2: 352), циитани́на 'брехня, обман' (Пиртей 2004: 333), циитани́ти 'брехати, обдурювати' (Пиртей 2004: 333), до вочей ичитанити 'говорити неправду; безсоромно брехати' (ФСЛГ 2013: 249), цитанска натура 'людина, яка часто говорить неправду, обманює' (ФСЛГ 2013: 155), повести ся поциитанскь 'обманути кого-небудь' (ФСЛГ 2013: 179).

Етнонім єврей та його похідні відсутні в опрацьованих лексикографічних працях, натомість його синонім етнонім жид має широку семантичну й морфемну розрослість. Пояснення цьому явищу слід шукати, вважаємо, в історико-політичній площині. Слушні міркування з цього приводу висловлюють історики: стара назва іудейської національності в українській мові жид - завжди була природна, назва ж єврей була імпортована разом з новою (радянською) владою. Вона звучала фальшиво, в народі не приживалась. Ця імпортованість назви євреїв, як зазначає Є. Сверстюк, була дивною і для них самих, які посміхалися 3 привілею називатися по-іншому і жартували: «І це все, що вони нам принесли» (СВЕРстюк 1996: 51). Отож укотре спостерігаємо, як діалектна система чинить опір чужій лексиці і демонструє не притаманну ій закритість.

Етнонім жид та його похідні експлікують такі «індивідуалізовані» мотиви:

а) мотив скупості й хитрощів: жид 'скупа хитра людина' (Аркушин 2016: 154), 'скупа хитра людина' (СУССГ 2002: 75), жидова́тый 'хитруватий, меркантильний' (САБАдош 2008: 84), жидом сі дивити 'дивитися жадібно, заздрісно' (ГС 2013: 262), крутити, як жид сонцем 'використовувати, послуговуватися, відверто знущатися’ (ГС 2013: 262), брати на жыдовску бороду ‘позичати без певної угоди’ (ФСЛГ 2013: 29);

б) мотив плачу: ридати як вічьний жид 'безутішно, сильно плакати, ридати’ (ГС 2013: 262), жи́дик ‘птах, який перед дощем квилить’ (Шило 2008: 116);

в) мотив неохайності: як в жида на ярмарку (моє), жид з торбою розбився ‘безлад’ (ДоьрольожА 2010: 70);

г) мотив лінощів: такий до роботи, як жид до иіпа 'дуже лінивий' (ГС 2013: 262), зберати ся як жыд на войну 'дуже повільний’ (ФСЛГ 2013: 99);

г) мотив діловитості, винахідливості: жид на кождій Марфі заробок має (ГС 2013: 262), жыдівскый довг ‘ірон., придане’ (ФСЛГ 2013: 78);

д) мотив неточності: жидівська міра 'неточна' (СПЛЛГ 2015: 64), жыдувска міра 'хто-небудь неточний, відхиляється від шкали вимірювання' (ФСЛГ 2013: 146); 
е) мотив інших традицій щодо харчування: мати піняжей як жыд пачят (свынь) 'ірон., зовсім не мати грошей' (ФСЛГ 2013: 140), як г жыда паият 'зовсім не має' (ФСЛГ 2013: 88), бояти ся як жыд солонини [солонина 'засолена про запас свинина' - І. Г.] ‘бути боязким, лякливим’ (ФСЛГ 2013: 88);

є) мотив іншої віри: стречы ся як жыд креста 'не порушувати моральних приписів, остерігатися небезпеки’ (ФСЛГ 2013: 88);

ж) мотив неспокою: як крутити ся як жыд по ярмаку 'бути неспокійним’ (ФСЛГ 2013: 88), бігати як жыд по прожнім склепі ‘бути неспокійним, метушитися' (ФСЛГ 2013: 88).

Етнонім жид та його похідні активно функціонують в усіх українських говірках зі значенням 'горобець, Passer': жид (Аркушин 2016: 154), жидо́к (АРкушин 2016: 154), жидик (Шило 2008: 116, Онишкевич 1: 251) та 'пропущене місце під час сівби вручну' : жд 'пропущене місце під час сівби вручну' (Аркушин 2016: 154), ‘пропуск в оранці' (ГГ 1997: 70), 'пропуск під час косіння’ (Шило 2008: 116), жидо́к ‘пропуск під час косіння’ (Аркушин 2016 : 154), жидні 'пропуски в косінні, в оранці' (СДЛВ 1965). Припускаємо, що ці лексико-семантичні паралелі пов'язані: за легендою, горобці своїм цвіркотінням видали Ісуса Христа переслідувачам, за що цей птах не користувався повагою і сприймався як нечистий птах (ГурА 1997: 586). Це могло послугувати мотиваційною базою для найменування птаха назвою іновірців - жид. Ототожнення українцями євреїв і горобців спричинило той факт, що найбільш сприятливим днем для сівби була субота: вважалося, що горобці разом з євреями справляють шабаш (суботній відпочинок) і тому не будуть завдавати шкоди посівам цього дня (Килимник 1963: 160). Можна припустити зв'язок цієї обрядодії та назвами пропуску під час сівби, похідними від етноніма жид. Погоджуємося, що наведені факти не $є$ повноцінними мотиваційними паралелями, позаяк між похідними значеннями немає системних зв'язків, та відмовлятися від припущення вважаємо недоречним, адже невичерпність образного потенціалу мови завжди дозволяс сподіватися на появу в майбутньому нових фактів: відсутніх на сьогодні ланок семантико-мотиваційних паралелей.

У відетнонімних дериватах лексеми поляк закодовано етнокультурну інформацію про мотив якісності: польський 'старанний, дбайливий', 'добрий, гарний, найкращого гатунку' (АРкушин 2016: 423), польські борщ ‘борщ, засмажений внутрішнім салом' (АРкушин 2016: 423). Цей номінативний ряд засвідчено в західнополіських говірках, натомість у тому ж ареалі засвідчено лексико-семантичний опозит ру́скій 'недбайливий, лінивий' (АРкушин 2016: 487). Припускаємо, що дві ознаки чужого - «високої якості» та «несправжність, фальшивість» - маніфестуються в назвах грибів, які за зовнішніми та смаковими характеристиками подібні до білого гриба, Boletus edulis: польський 'гриб їстівний із бурою шапкою, жовтувато-зеленуватого зісподу; моховик, Boletus badius Rr.' (МАтіїв 2013: 369), польський гриб 'гіропор синючий, Xerocomus badius [за іншою класифікаційною системою належить до роду Boletus - I. Г.]' (АРКушин 2016: 422), поляк 'вид гриба' (Онишкевич 2: 109), польський гриб 'польський гриб, Boletus badius Fr.' (ГорОФ’янюк 2012: 131). 
Малочисельні похідні від основи mamap- метафорично кодують етнокультурну інформацію про об'єкт великого розміру: йак татар 'великий, сильний, витривалий' (Турчин 2011: 310), тата́рка 'сорт великої білої квасолі' (Шило 2008: 250). Вторинні флороназви татарки́ 'листя зеленої цибулі' (Аркушин 2016: 547), татарка 'цибуля-сіянка' (Лисенко 1974: 211), припускаємо, виникли за подібністю листя молодої цибулі до листя лепехи, Acorus L., яку в українських говірках називають тата́p, тата́pка, mamápське зілля, тата́рник, тата́рщинна (КоБів 2004: 38).

Таким чином, спостережено, що в українських діалектах етноніми як дериваційна база використовуються двовекторно. По-перше, як засіб лексичної номінації (переважно формальної) реалій за місцем-джерелом, способом їхнього поширення, за колористичною характеристикою. По-друге, як засіб наївної аксіології - кодування оцінки етнокультурної інформації. Ця група відетнонімних назв представлена переважно семантичними дериватами 3 прозорою мотивацією.

Засвідчено чітко окреслений ряд тематичних груп лексики, де функціонують відетнонімні похідні: назви рослин, тварин, хвороб, метеорологічна лексика, назви предметів побуту, оцінні назви людини тощо.

Семантична розрослість етноніма, його конотативний потенціал виявилися зумовленими історичними, соціальними та культурними чинниками: у національній концептосфері українців найбільш значимими виявилися етноси євреїв та циган. Зауважимо, що хоча за кожним етнонімом закріплено певний набір мотиваційних / оцінних ознак - від 1 (турок, молдаван) до 9 (жид), - та в наївній аксіології українського діалектоносія всі твірні етноніми мають універсальне мотиваційне значення «чужий», про що виразно свідчить лексична варіативність відетнонімних назв, наприклад, московська зозуля, жидівська зозуля 'одуд, Upupa epops' у поліщуків (Никончук 1968: 450). 3 огляду на це не можна прямо експлікувати оцінку якогось етноніма, закріплену в слові, на сам етнос.

\section{Джерела}

АРкУшин 2016 = АРкушин Г. Словник західнополіських говірок. Луцьк, 2016.

АСТАФ'СВА-ВОРОнич 2014 = АСТАФ'СВА М. М., ВоРОнич Г. В. Словник гуиульських говірок Річки та Яворова. Кн. 1. Івано-Франківськ, 2014.

БЕРЕЗОВСЬКА 2010 = БЕРЕЗОВСЬКА Г. Г. СЛовник назв одягу та взуття у східноподільських говірках. Умань, 2010.

ГГ 1997 = ЗАКРЕВСьКА Я. (ред.) Гуиульські говірки. Короткий словник. Львів, 1997.

ГОРОФ'янюк 2012 = ГоРОФ'янЮк І. В. Ботанічна лексика изентральноподільських говірок. Матеріали до Лексичного атласу украӥнської мови. Вінниця, 2012.

ГС 2013 = Гуиульські світи. Лексикон. Львів, 2013.

ДЗЕНДЗЕЛІВСЬКИЙ 1958 = ДЗЕНДЗЕЛІВСьКИЙ Й. О. Практичний словник семантичних діалектизмів Закарпаття. Ужгород, 1958.

ДоБРОЛЬОЖА $2010=$ ДоБРОЛЬОЖА Г. Фразеологічний словник говірок Житомирщини. Житомир, 2010. 
ЕСУМ = Етимологічний словник української мови. Т. 1-6. Київ, 1982-2012.

КоБІв 2004 = КоБІв Ю. Словник українських наукових $і$ народних назв судинних рослин. Київ, 2004.

ЛИСЕНКО 1974 = ЛИСЕНКО П. С. СЛовник полісьКих говорів. Київ, 1974.

МАтї̈в 2013 = МАтї̈в М. Д. Словник говірок Центральної Бойківщини. Київ-Сімферополь, 2013.

МосКАЛЕНКО 1974 = МоскАЛЕНКО А. А. Словник діалектизмів украӥнських говірок Одеської області. Одеса, 1958.

НЕГРИч 2008 = НЕГРИч М. Скарби гуиульського говору. Березови. Львів, 2008.

Никончук $1968=$ Никончук Н. В. Полесские названия птиц. В кн.: Лексика Полесья. Материалы для полесского диалектного словаря. Москва, 1968. 439-471.

ОНИшКЕВИЧ 1984 = ОНИшКЕВич М. Й. Словник бойківських говірок. Ч. 1-2. Київ, 1984.

ПиРТЕЙ 2004 = ПиРТЕй П. Короткий словник лемківських говірок. Івано-Франківськ, 2004.

ПІПАШ-ГАЛАС 2005 = ПІПАШ Ю., ГАЛАС Б. Матеріали до словника гуиульських говірок. Косівська Поляна і Росішка Рахівського району Закарпатської області. Ужгород, 2005.

САБАДОШ 2008 = САБАДОШ І. Словник закарпатської говірки села Сокирниия Хустського району. Ужгород, 2008.

СБГ 2005 = ГУЙВАНЮк Н. (ред.) Словник буковинських говірок. Чернівці, 2005.

СДЛВ 1965 = Словник діалектної лексики Вінниччини. Вінниця, 1965. [Машинопис.]

СПЛЛГ 2015 = Словник прикметникового лексикону лемківських говірок. Тернопіль, 2015.

СРГО 2000-2001 = КАРПЕНКО Ю., УЭМУРА С. (ред.) Словарь русских говоров Одесщзиныл. Т. 2. Одесса, 2000-2001.

СУГО 2011 = БОНДАР О. І. (ред.) Словник украӥнських говорів Одещини. Одеса, 2011.

СУМ 1908 = Грінченко Б. Д. (ред.) Словарь української мови. Т. 2. Київ, 1908.

СУССГ 2002 = Словник українських східнослобожанських говірок. Луганськ, 2002.

Турчин 2011 = Турчин Є. Д. Словник села Тирлич на Лемківщині. Львів, 2011.

ФСЛГ 2013 = Фразеологічний словник лемківських говірок. Тернопіль, 2013.

Шило 2008 = Шило Г. Наддністрянський регіональний словник. Львів-Нью-Йорк, 2008.

NKP 1970 = KRZYŻANOWSKI J., ŚWIRKO S. (red.) Nova księga przystów i wyrażeń przystowiowych polskich. T. 2. Warszawa, 1970.

OED 1989 = Simpson J. A., WeInER E. S. (ed.) The Oxford English Dictionary. Vol. 7. Oxford, 1989.

\section{Література}

БЕЛОВА 2006 = БЕЛОВА О. В. Этнические стереотипы по данным языка и народной культуры славян (этнолингвистическое исследование). АДД. Москва, 2006.

БЕРЕЗОВИч 2007 = БЕРЕЗОВИч Е. Л. Язык и традиционная культура. Этнолингвистические исследования. Москва, 2007.

БЕРЕЗОВИч 2014 = БЕРЕЗОВИч Е. Л. Русская лексика на общеславянском фоне. Семантико-мотивациионная реконструкция. Москва, 2014.

БЕРЕЗОВИЧ-ГУЛИК 2002 = БЕРЕЗОВИч Е. Л., ГУлИк Д. П. Ноmo ethnicus в зеркале языка: к методике описания. Etnolingwistyka. Problemy jazyka i kultury 14 (2002): 47-67. 
ГОРОФ'янюк 2010 = ГоРОФ'янюк I. Етноніми як база творення українських флорономенів. В кн.: Мовознавчі студіі. Діалект у лінгвокультурологічному прострі. Вип. 3. Дрогобич, 2010. 42-50.

ГурА 1997 = ГурА А. В. Символика животных в славянской народной традиции. Москва, 1997.

ДЗЕНДЗЕЛІВСьКИЙ 1960 = ДЗЕНДЗЕЛІВСьКИй Й. О. Назви сільськогосподарських культур у говорах Закарпаття. Studia Slavica Hung. 6 (1960): 113-143.

КАшКИН $2000=$ КАшКИН В. Б. Этнонимы и территория национальной души. В кн.: КАшкИН В. Б., ПЁЙХЁНЕН С. Русское и финское коммуникативное поведение. Воронеж, 2000. 62-70.

КАшКИН 2004 = КАшКИН В. Б. Маркеры своего и чужого в межкультурном диалоге. В кн.: ГрИШАЕВА Л. И., ПоПОВА М. К. (ред.) Взаимопонимание в диалоге культур. Условия успешности. Ч. 2. Воронеж, 2004. 49-62.

Килимник 1963 = Килимник С. Український рік у народніх звичаях в історичному освітленні. Т. 5. Осінній цикль. Вінніпег, 1963.

КоБОЗЕВА 2000 = КОБОЗЕВА И. М. Конкретный пример лексико-семантического эксперимента. Выявление стереотипов национальных характеров через анализ коннотаций этнонимов. В кн.: КоБОзЕВА И. М. Лексическая семантика. Москва, 2000. $185-196$.

ЛЕВКИЕВСКАЯ 1999 = ЛЕВКИЕВСКАЯ Е. Е. Игры народные. В кН.: ТоЛСТОЙ Н. И. (ред.) Славянские древности. Этнолингвистический словарь. Т. 2. Москва, 1999. 380388.

ПогстоговА 2005 = ПогстоговА М. В. Номінаційні процеси у ботанічній лексиці східнополіських говірок. Дис. ... канд. філол. наук. Київ, 2005.

САБАДОШ 1996 = САБАДОШ І. В. Формування української ботанічної номенклатури. Ужгород, 1996.

СВеРСТЮК 1996 = СВеРСТЮК С. Шевченко і час. Київ, 1996.

ШАмотА 1985 = ШАмОтА А. М. Назви рослин в украӥнській мові. Київ, 1985.

BUDZISZEWSKA 1972 = BUDZISZEWSKA W. Zwiazki polsko-ruskie w zakresie terminologii botaniczej. Studia z filologii polskiej i slowianskiej 11 (1972): 113-121. 